\title{
Investigation of tectonically affected groundwater systems through a multidisciplinary approach
}

\author{
R. Gambillara ${ }^{\text {a }}$, S. Terrana ${ }^{\text {a,* }}$, B. Giussani ${ }^{a}$, D. Monticelli ${ }^{a}$, S. Roncoroni ${ }^{a}$, S. Martin ${ }^{\text {b }}$ \\ a Università Degli Studi dell'Insubria, Di.S.A.T., via Valleggio, 11 I-22100 Como, Italy \\ ${ }^{\mathrm{b}}$ Università Degli Studi di Padova, Dipartimento di Geoscienze, via Gradenigo, 6 I-35100 Padova, Italy
}

\section{A R T I C L E I N F O}

\section{Article history:}

Received 15 May 2012

Accepted 9 January 2013

Available online 23 January 2013

Editorial handling by I. Cartwright

\begin{abstract}
A B S T R A C T
This study uses a multidisciplinary approach to obtain a complete picture of the groundwater system of complex mountain aquifers. An Alpine region (the north-western area of Lake Como, Italy), characterized by two regional fault systems (The Breglia and Grona fault systems) containing different lithologies, was investigated using the multidisciplinary approach described here. The use of Principal Components Analysis (PCA), classical geochemical bivariate and trivariate diagrams of major and trace elements, and geostructural data, including remote sensing, permitted the identification of three principal groups of water. The first group, characterized by an enrichment of $\mathrm{Ca}^{2+}$ and $\mathrm{HCO}_{3}^{-}$, flow in limestone. The second group is enriched in $\mathrm{HCO}_{3}^{-}, \mathrm{Ca}^{2+}$ and $\mathrm{Mg}^{2+}$ and circulates through dolomite rocks. The third group, characterized by a decrease of $\mathrm{Ca}^{2+}$ and $\mathrm{Mg}^{2+}$, an increase of $\mathrm{Na}^{+}+\mathrm{K}^{+}$and a high Si/electrical conductivity (EC) ratio, flow in the basement rocks. Nevertheless, some peculiarities were evident. The matching of PCA, hydrochemical and geostructural information explains the role played by faults in water circulation. In particular, the Breglia fault permits the rise of deep water from crystalline basement and dolomite. Similarly, the Grona fault plays a role on drainage in proximity to the contact between the crystalline basement and the sedimentary cover. The springs located near the Grona fault rise into the crystalline basement but reflect a dolomite water chemistry. The multidisciplinary approach allowed understanding of the groundwater system and identification of fault systems not detectable with a geostructural survey.
\end{abstract}

(c) 2013 Elsevier Ltd. All rights reserved.

\section{Introduction}

The chemical composition of springs has been studied extensively in the past with the purpose of both establishing their quality for possible human exploitation and for defining geochemical signatures to establish groundwater flow paths. These topics are clearly connected as the understanding of the groundwater system is mandatory for the assessment of water resources, their exploitation and safety (see e.g. the recent review Hua et al., 2011; Kacaroglu, 1999, for karst aquifers). Nevertheless, structural features of the host rock formations may severely complicate the identification of groundwater flow. Tectonic control has been demonstrated to strongly affect groundwater circulation (e.g. Earman et al., 2008; also Civita, 2005; Scesi and Gattinoni, 2007; Goldscheider and Neukum, 2010 for the Alpine region) both directly (faults acting as preferential pathways or barriers) and indirectly (induced rock fracturing). Rock fracturing, whatever its origin, is a second factor strongly affecting aquifer structure and groundwater flow: fractured rocks are neither homogeneous nor isotropic, making the identification of their flow patterns a particularly challenging task (e.g. reviewed by Neuman (2005) and Eaton (2006)). As a final fac-

\footnotetext{
* Corresponding author. Tel.: +390312386616.

E-mail address: silvia.terrana@uninsubria.it (S. Terrana).
}

tor, the combination of fast and slow flow patterns in karst systems make groundwater modelling a challenging task (e.g. the classical review by Legrand and Stringfield (1973), and the more recent one by Ghasemizadeh et al. (in press)). As an additional consideration, weathering and/or paleoweathering in non-karst systems has been proposed recently as a major factor influencing groundwater circulation (e.g. Lachassagne et al., 2011).

This complexity has been addressed by different methods. Modelling clearly continues to play a major role (e.g. Neuman, 2005; Eaton, 2006; Ghasemizadeh et al., in press), although two major issues hinder its widespread application. First, data on aquifer structure (e.g., rock fracturing and permeability) should be available, which is seldom the case when extensive Quaternary cover strongly limits the outcrops (e.g. Terrana et al., 2010). Second, modelling of complex areas including several fault systems and a complex topography is beyond present possibilities. The use of geochemical tracers is an alternative, indirect approach for the understanding of groundwater circulation (e.g. Banks et al., 1998). These methods make use of geochemical plots to classify waters on the basis of their chemical composition and to infer their circulation.

In this paper, it is shown that the issues posed by complex groundwater systems may be efficiently addressed by using different integrated methodologies such as: multivariate analysis (Prin- 
cipal Component Analysis, PCA), traditional geochemical methods (comparison plots) and geostructural analyses. The method is applied to an Alpine region (the north-western area of the Lake Como basin, Italy) that is characterized by several fault systems (including one of regional relevance separating the crystalline basement and the sedimentary cover), different lithologies, and complex topology. The area is lacking in outcrops and has a large number of springs. To the best of the authors' knowledge, such an integrated approach has never been undertaken to study such a complex area, although examples of the use of PCA for groundwater characterization may be found in the literature (Stetzenbach et al., 1999; Koonce et al., 2006; Dassi, 2011). As a result, this integrated method allows full characterization of mountain aquifers with complex geological conditions and the assessment of the role played by faults and fracture systems on groundwater circulation.

\section{Study area}

\subsection{Physiographic setting}

The investigated area is situated in northern Italy, in the northern-western part of the Lake Como basin with a total area of $55 \mathrm{~km}^{2}$ (Fig. 1). It extends in a N-S direction between the towns of San Siro and Menaggio, and in an E-W direction between San Siro and Carlazzo. The study area is sparsely populated, and the population is concentrated in small towns. The local topography is represented by a foothill zone surrounded by WNW-ESE and E-W oriented mountains. Ground elevation ranges from about $200 \mathrm{~m}$ a.s.l. near Lake Como and $2245 \mathrm{~m}$ a.s.l. of the mountain Pizzo di Gino, located in the NW part of the study area. The hydrographic setting is poorly developed. In general, there are many small streams, often without water. Senagra and Cuccio are the principal torrents. The Senagra torrent rises south of Monte Bregagno and flows into Lake Como near Menaggio. The Cuccio torrent rises in the Pizzo di Gino mountain and flows into Lake Lugano near Porlezza. In the study area, there are also two lakes: Lake Como situated in the eastern part, and Lake Piano, located in the central part south of Carlazzo.

The valley area, Val Menaggio, is the location of productive activities (e.g., bottling of mineral water and other beverages, and tourism) and agricultural use of the land, while in the other parts of the study area, the typical vegetation of a pre-alpine zone is present. The climate of the region is influenced by many factors: the collision of the moist and temperate air of the Mediterranean Sea and the Atlantic Ocean with the cold air of the European continent; the presence of the Alpine chain, which creates breaks in air masses; and the presence of big pre-alpine lakes (Lugano and Como Lakes), which have mesoclimatic effects (Belloni and Cojazzi, 1985). The annual rainfall is about $1200 \mathrm{~mm}$ with the maximum in July and the minimum in December (2006-2010 data - Centro Geofisico Prealpino Lariano).

\subsection{Geological setting}

The area of interest belongs to the Southern Alps domain. It is located several tens of $\mathrm{km}$ to the South of the Periadriatic lineament. This lineament separates the Southern Alps from the Austroalpine and Penninic domains (Vai et al., 1981; Bertotti, 1991; Schumacher et al., 1996). The geological setting is characterized by the crystalline metamorphic basement of the Southern Alps and by the Permo-Triassic sedimentary cover (Figs. 1 and 2). The crystalline basement (pre-Westfaliano; Perotti, 1987), located in the northern part of the area (Fig. 1), is characterized by micaschist and staurolite gneiss and muscovite orthogneiss (Gneiss Chiari; Boriani and Colombo, 1979; Spalla et al., 2000). The muscovite orthogneiss consists of amphibolite grade heterogeneous gneiss, highly deformed and poorly defined (Bertotti, 1991). The micaschist and staurolite gneiss consist of gneiss and metamorphosed schist, which were deformed in amphibolitic conditions (Reinhard, 1953; Boriani et al., 1977).

The sedimentary cover is characterized by lithologies from Permian age to Jurassic age (Gianotti and Tannoia, 1988; Bertotti, 1991; Fig. 2); it consists mainly of conglomerate, sandstone, limestone and dolomite (Renevier, 1879; Lehner, 1952; Casati, 1964; Allasinaz, 1968; Kalin and Trumpy, 1977; Farabegoli and De Zanche, 1984; Gianotti, 1984; Gaetani et al., 1986; Bernoulli et al., 1990; Bertotti, 1991). The Permian-Schitic units outcrop in the east part of the study area and are represented by the Verrucano and Servino Formations. These consist of matrix-supported conglomerates and grain-supported sandstones (Lehner, 1952; Fig. 2). The Triassic series outcrop in the central and western parts of the study area (Fig. 1). They are characterized by dolomite (San Salvatore Dolomite and Dolomia Principale), limestone (Cunardo Formation), marly limestone ( $\mathrm{u}$ Limestone), limestone with evaporitic bodies (Raibl Beds), bituminous limestone (Zorzino Formation) and dolomite conglomerate (Ligomena Breccia; Fig. 2). The Jurassic series outcrop in the southern part of the area; they consist of dolomite (Conchodon Dolomite) and siliceous limestone (Moltrasio Limestone; Fig. 2). Quaternary deposits include glacial deposits, landslide deposits, alluvional deposits and conoid (Fig. 1).

The investigated area is crossed by an important longitudinal fault of the Alpine chain (Grona fault), and a transversal one (Breglia fault; Fig. 1). The Grona fault, in the western and central part of the area, assumes an ENE-WSW trend, while in the eastern part, it has a NW-SE trend. This is a high angle fault, which divides the crystalline basement to the north from the sedimentary cover to the south (Bertotti, 1991; Venzo and Maglia, 1947; Lehner, 1952). The Breglia fault is a NE-SW strike-slip fault that divides the Monte Grona Dolomite to the west from the Nobiallo region sequence to the east (Bertotti, 1991).

The hydrogeological setting of the area is inadequately described by some technical reports made by the local municipalities. These data are insufficient to discriminate the different aquifers and the routes of water circulation. Pozzi (1962) and Francani (1986) distinguished five hydrogeological series in the study area, characterized by different permeability: the crystalline basement, Verrucano and Servino Formations; Raibl Beds; Dolomia Principale; Calcare di Zu; Conchodon Dolomite and Moltrasio Limestone. In particular, the Dolomia Principale, Conchodon Dolomite and Moltrasio Limestone series are characterized by high water circulation (Francani, 1986). In the northeastern (or northern and eastern parts) part of the study area, permeability is high (from $1.2 \times 10^{-3}$ to $8.7 \times 10^{-4} \mathrm{~m} / \mathrm{s}$; Gambillara, 2005); this is due to the strong fracturing from the tectonic activity in the area (Gambillara, 2005). Gambillara (2005) developed a distribution map of permeability that highlighted the high permeability values in proximity to faults.

\section{Material and methods}

In this study, a spring sampling campaign and a geostructural survey were undertaken: 30 springs were sampled and a geostructural analysis was performed in 17 sites of the investigated area (Figs. 1 and 3). Springs were sampled during spring-summer 2010 as follows: 18 rising into sedimentary rocks, 5 into the crystalline basement and 7 into glacial deposits (Table 1). Five of these springs are located near the contact between the sedimentary rocks and the basement along one of the fault zones (Fig. 3). Some of the springs are situated in areas or places with peculiar geological settings: Mn2 and Mn3 springs rise in a glacial deposit in prox- 


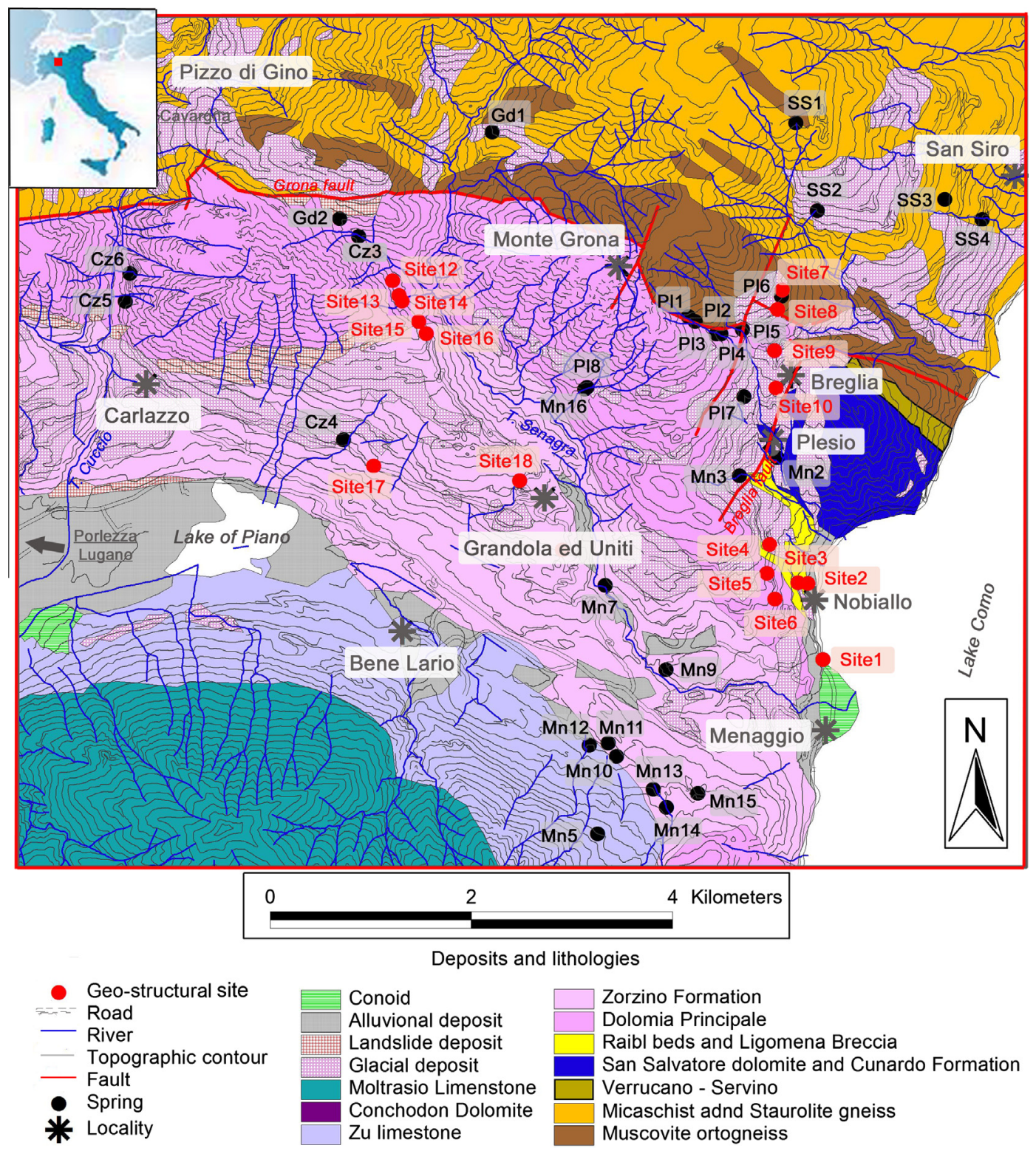

Fig. 1. Location and geological map of the study area.

imity to the Breglia fault system; Pl1, Pl2, Pl3, Pl4 and Pl5 springs are located near the contact between muscovite orthogneiss and Dolomia Principale along the Grona fault system (Fig. 1).

\subsection{Water sampling and chemical analyses}

Ultrapure water from a Millipore MilliQ system $(18 \mathrm{M} \Omega \mathrm{cm}$ resistivity) and ultrapure concentrated $\mathrm{HCl}$ and $\mathrm{HNO}_{3}$ (Suprapure from Fluka) were used throughout. Low-density polyethylene (LDPE) sampling bottles (trace element analysis) and polypropylene vials (ion chromatography determinations) were washed and stored in $6 \mathrm{M} \mathrm{HCl}$ solution. Bottles and vials were thoroughly rinsed with ultrapure water before use. Water samples were collected by hand. Aliquots for ion chromatography were syringe filtered in the field and acidified $\left(\mathrm{HNO}_{3}\right.$, final $\left.\mathrm{pH}=2\right)$ in the case of cation determination. Aliquots for trace element determination were filtered using prewashed $0.45 \mu \mathrm{m}$ nitrocellulose filters and stabilized to $\mathrm{pH}=2$ with $\mathrm{HNO}_{3}$. All solution preparation and sample manipulations in the laboratory were executed in a class 100 laminar-flow hood to minimize external contamination.
Physical chemical parameters (temperature, $\mathrm{pH}$ and Electrical Conductivity - EC) were determined in the field using portable instrumentation: a HANNA HI $9025 \mathrm{pH}$ meter and a pIONeer 65 conductivity meter equipped with a temperature probe. The instruments were calibrated daily in the field before sampling. Reactive silica (labelled as $\mathrm{Si}$ in this article) was determined using an Aquamerck portable kit from Merck Eurolab. The concentration of major ions was determined in the laboratory by ion chromatography with an automated IC761 instrument (Metrohm, Herisau, Switzerland) equipped with conductometric detection and an autosampler (Metrohm 831 Compact Autosampler). Anion determination was performed on a Metrosep A Supp 5-250 column with a $1.5 \mathrm{~mL} / \mathrm{min}$ eluent flux $\left(3.2 \mathrm{mM} \mathrm{Na}_{2} \mathrm{CO}_{3}+1.0 \mathrm{mM} \mathrm{NaHCO}{ }_{3}\right)$. Cation analysis was carried out using a Metrosep Cation C2 150 column, a $4.0 \mathrm{mM}$ tartaric acid and $0.75 \mathrm{mM}$ dipicolinic acid eluent and no chemical suppression, with a $1.0 \mathrm{~mL} / \mathrm{min}$ flow rate. Anions and cations were quantified by external calibration curves. To assure data accuracy, the instrumental calibration for each analyte was performed daily by accurate dilution of a $1000 \mathrm{mg} / \mathrm{L}$ standard solution (Merck) acidified to $\mathrm{pH}=2$ with $\mathrm{HNO}_{3}$ in the case of cation 


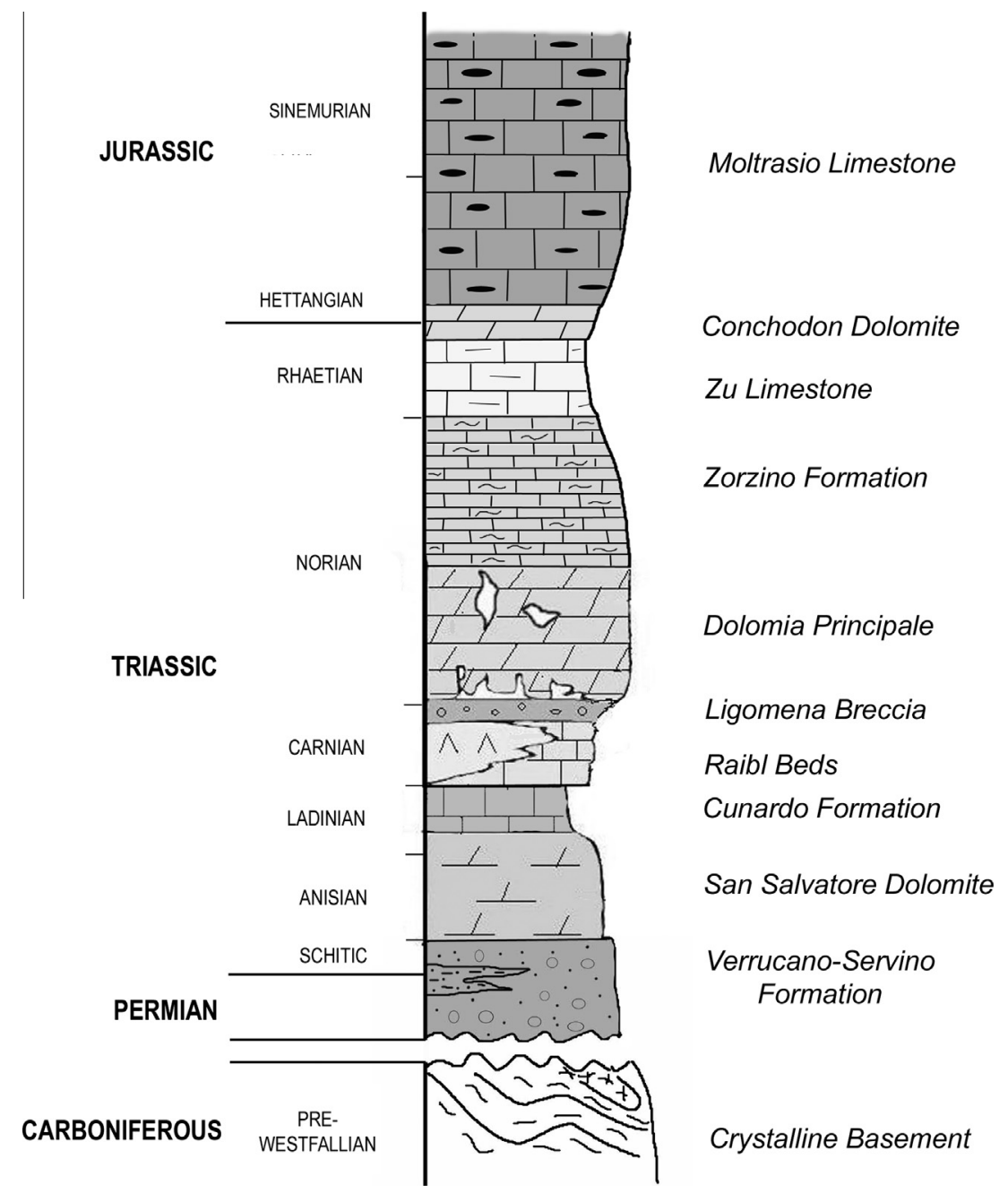

Fig. 2. Lithostratigraphic column of the study area.

determinations. The measured limits of detection (LOD) were $5 \mu \mathrm{g} /$ $\mathrm{L}$ for anions and 5-20 $\mu \mathrm{g} / \mathrm{L}$ for cations, respectively, (estimated following the International Union of Pure and Applied Chemistry IUPAC rules, 1995). The relative percentage standard deviations (RSD\%) were $2-5 \%$.

Total alkalinity (essentially $\mathrm{HCO}_{3}^{-}$) was determined via an acidbase potentiometric titration with standardised $\sim 0.01 \mathrm{M} \mathrm{HCl}$ : the equivalence point was calculated using Gran's plot (Dossi et al., 2000).

Trace element determinations were performed using a VG Elemental PlasmaQuad 3 Inductively Coupled Plasma-Mass Spectrometry (ICP-MS). The optimization of the instrument was performed as recommended by the manufacturer by tuning with a $10 \mu \mathrm{g} / \mathrm{L}$ multi-standard solution. Standard solutions for external calibration were prepared daily by dilution of a $10 \mathrm{mg} / \mathrm{L}$ multistandard solution (Merck) and acidified to 2\% with Suprapur $\mathrm{HNO}_{3}$. The following isotopes were measured: ${ }^{7} \mathrm{Li},{ }^{11} \mathrm{~B},{ }^{27} \mathrm{Al},{ }^{51} \mathrm{~V}$, ${ }^{53} \mathrm{Cr},{ }^{55} \mathrm{Mn},{ }^{57} \mathrm{Fe},{ }^{59} \mathrm{Co},{ }^{60} \mathrm{Ni},{ }^{65} \mathrm{Cu},{ }^{66} \mathrm{Zn},{ }^{75} \mathrm{As}$ and ${ }^{85} \mathrm{Rb}$, as suggested by the manufacturer (the selection of the isotope for every element is a compromise between sensitivity, isotopic abundance and lack of isobaric interferences). The signal recorded at $\mathrm{m} / \mathrm{z} 75$ for As was corrected because of the known polyatomic interference due to the formation of the ${ }^{75} \mathrm{ArCl}$ species:

${ }^{75} \mathrm{As}=75 \mathrm{ICPS}-3.127(77 \mathrm{ICPS}-0.81582 \mathrm{ICPS})$,

where 75 ICPS, 77 ICPS and 82 ICPS denote the Integrated Counts Per Second registered at $\mathrm{m} / \mathrm{z} 75,77$ and 82, respectively, (see Envi- ronmental Protection Agency (EPA) method 200.8 as an example). The LODs of all elements were estimated following IUPAC rules (1995) and ranged from $0.20 \mu \mathrm{g} / \mathrm{L}$ for lighter elements ( $\mathrm{Li}$ and B) down to $2-10 \mathrm{ng} / \mathrm{L}$ for $\mathrm{Co}, \mathrm{Zn}, \mathrm{Pb}$ and $\mathrm{U}$. Radon-222 activity was measured by the Electret Ion Chamber method using an E-PERM system from Rad Elec Inc. (Kotrappa et al., 1988; Kotrappa and Jesters, 1993; Fjeld et al., 1994; Kotrappa, 2008). All analyses were carried out in the Analytical Chemistry Research Laboratory, University of Insubria, Como.

\subsection{Groundwater chemistry}

Data processing was done using qualitative plots, such as triangular diagrams, bivariate plots and Chebotarev diagrams (Chebotarev, 1952; Celico, 1986; Faure, 1996). Contours, or distribution graphical models were obtained using the software Surfer (version 8.03 - Golden Software, Inc., Colorado, USA). The implementation of the dataset was done using the kriging approach, which includes a group of geostatistical techniques that interpolate the random field values, fitting them in a family of linear least squares estimation algorithms (Krige, 1951; Matheron, 1963; Agterberg, 1974; Isaaks and Srivastava, 1989). The axes of the Chebotarev diagram (Fig. 4a) shows $\mathrm{HCO}_{3}^{-}, \mathrm{Ca}^{2+}+\mathrm{Mg}^{2+}, \mathrm{Cl}^{-}+\mathrm{SO}_{4}^{2-}$ and $\mathrm{Na}^{+}+\mathrm{K}^{+}$values normalized to 50 . This plot enables the detection of groups of water with similar features. Its results should be combined to the ones obtained by triangular diagrams to give more accurate information about the water classification. The axes of the triangular 

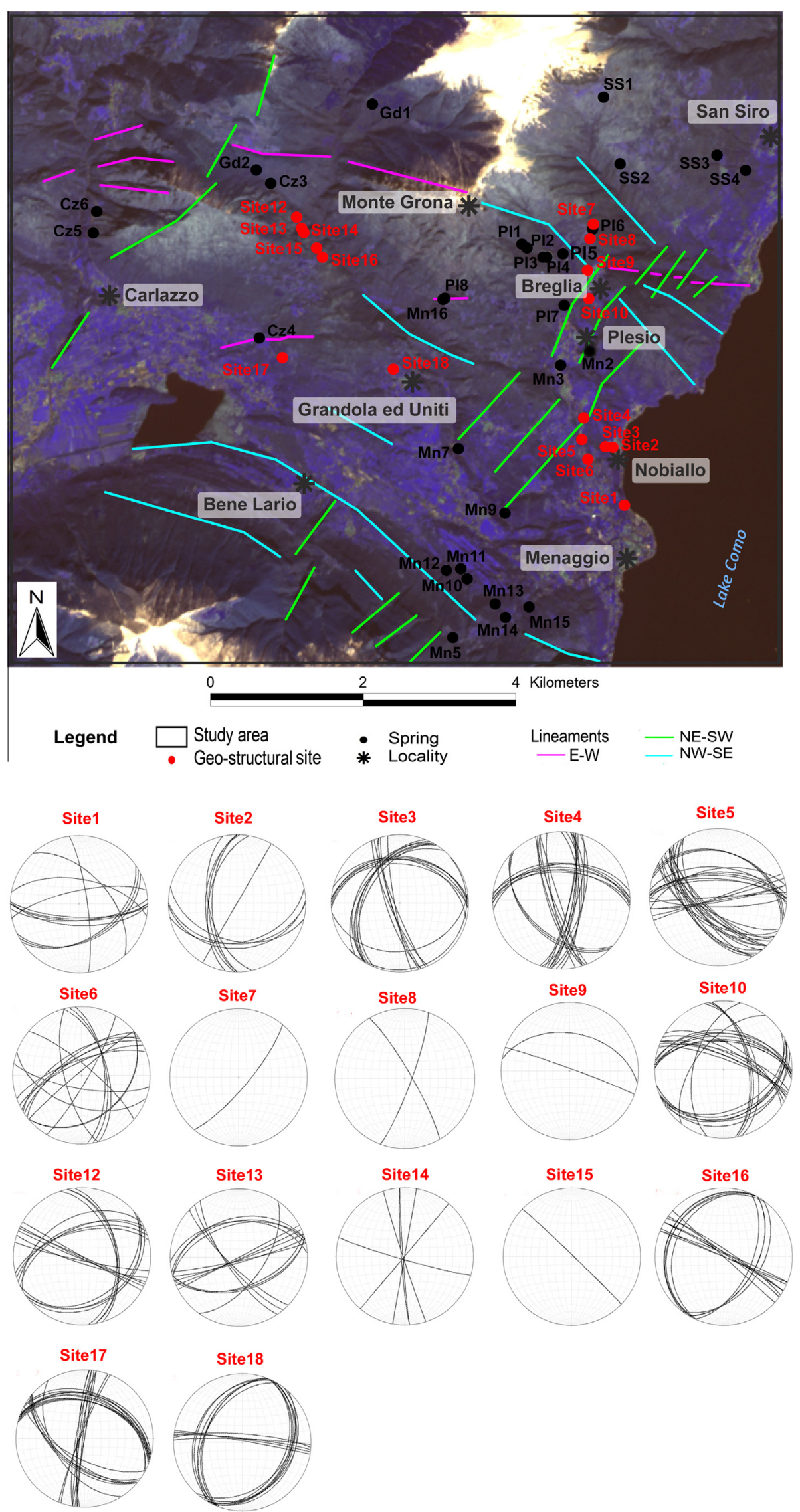

Fig. 3. Remote sensing (ASTER-1991005 multispectral image - false colour composite 1, 2, 3 band) and geo-structural analysis of the study area. 

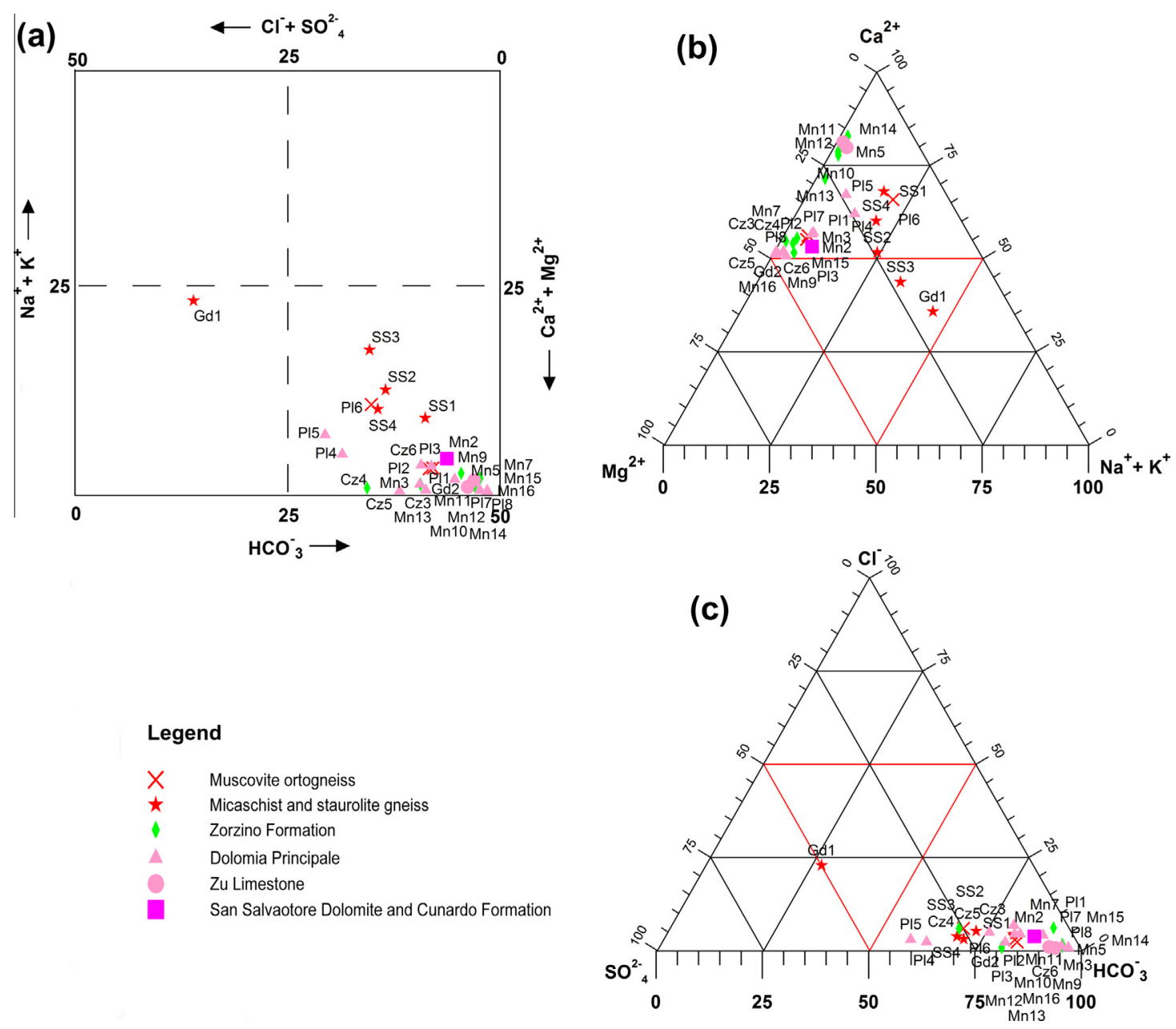

Fig. 4. Chebotarev diagram (a), cation (b) and anion (c) triangular diagrams of the studied water springs.

diagrams show ion content values normalized to 100 (Fig. $4 \mathrm{~b}$ and c). The anion triangular diagram analyzes $\mathrm{Cl}^{-}, \mathrm{SO}_{4}^{2-}$ and $\mathrm{HCO}_{3}^{2-}$, while the cation triangular diagram analyzes $\mathrm{Ca}^{2+}, \mathrm{Mg}^{2+}$ and $\mathrm{Na}^{+}+\mathrm{K}^{+}$.

Several bivariate plots between major and trace elements were also done to identify water-rock interaction processes.

\subsection{Principal Component Analysis (PCA)}

Principal Component Analysis (PCA) is a powerful exploratory data analysis method that allows finding patterns in data through a visual approach. It provides a graphic representation of the relationships between samples and variables and provides insights into how measured variables cause some samples to be similar to, or different from, each other. It can thus be used to reveal a hidden structure within large or complex data sets. As it simultaneously takes into account all of the variables involved, it can be a powerful tool in hydrochemical studies. The algorithm transforms a number of possibly correlated variables into a smaller number of uncorrelated (orthogonal) variables, called Principal Components. The first Principal Component explains as much of the variability in the data as possible, and each succeeding component explains as much of the remaining variability as possible. The results of a PCA model are usually analyzed by interpreting the resulting Score and the Loading plot. The former describes the coordinates of the objects (samples) on the PCs and allows finding sample differences or similarities, while the latter shows the data structure in terms of variable contributions and correlations. Principal Component Analysis was performed using the software The Unscrambler (version X - CAMO AS, Trondheim, Norway) by applying the Nonlinear Iterative Partial Least Squares (NIPALS) algorithm. The NIPALS algorithm was developed by Wold et al. (1987), first for PCA and later for PLS, and has become the most commonly used method for calculating the principal components of a data set. It gives more numerically accurate results when compared with the SVD (singular value decomposition) of the covariance matrix and dramatically reduces the computational time since calculation of the covariance matrix is avoided. Prior to the calculation, autoscaling was performed in order to give all of the variables an equal chance to influence the PC construction. This pretreatment produces variables with zero mean and unit standard deviation. Loading and score plots for the first informative principal components were discussed. Data below the limit of detection were replaced with half of the detection limit (LOD/2). The alternative choice of filling data with any numbers lying between LOD and zero did not significantly change patterns in the score plot.

\section{Results}

\subsection{Geostructural data}

The geostructural studies were carried out using remote sensing to identify the main lineaments and the detailed geostructural survey. The geostructural sites are distributed in three zones (Fig. 3): 

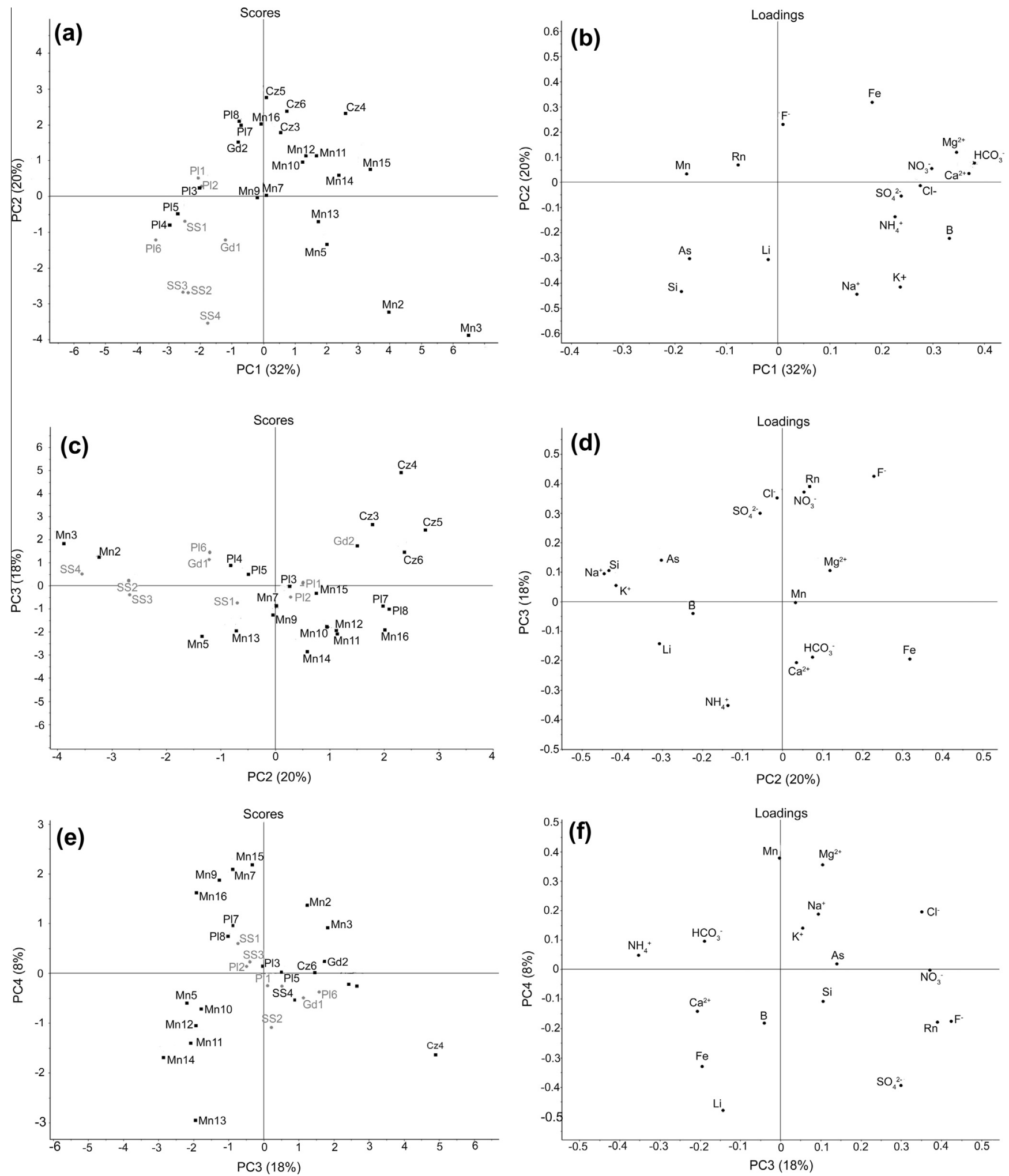

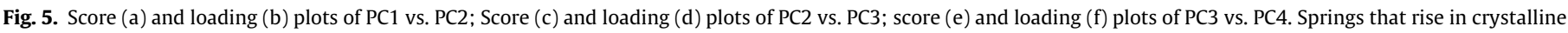
basement and springs in sedimentary cover are represented in light grey and black colours, respectively, in score plots.

the high Val Senagra (Sites12, 13, 14, 15, 16, 17 and 18), the Nobiallo (Sites1, 2, 3, 4, 5 and 6) and the Plesio (Sites 7, 8, 9 and 10) areas. In the Val Senagra area, the remote sensing identified EW, NE-SW and NW-SE trends of lineaments. Three main fracture systems were measured in this area (Fig. 3): one in the direction from WNW-ESE to NW-SE (trend of the valley), one with an approximately $\mathrm{N}-\mathrm{S}$ direction and the third one NE-SW directed. Two strike-slip faults were also measured, with E-W and ENEWSW trends, respectively, approximately parallel to the Grona fault. In the Nobiallo area, the NE-SW oriented lineaments were identified, and one persistent E-W fracture system and one oriented from NNE-SSW to NE-SW were surveyed (Fig. 3). These sys- 
(a)

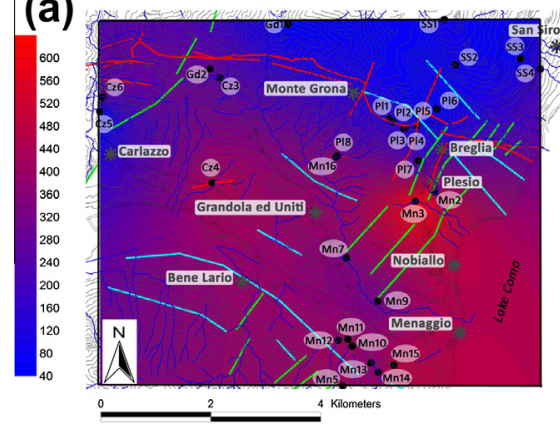

(b)

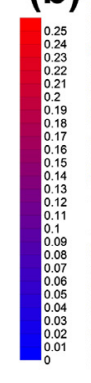

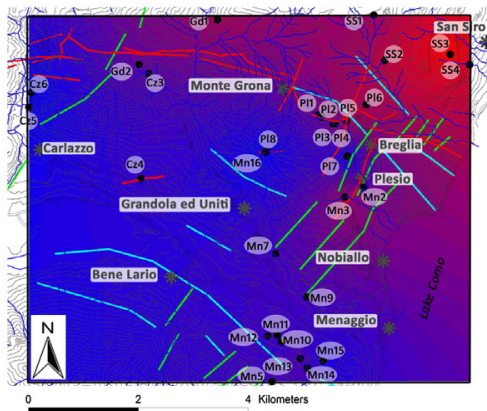

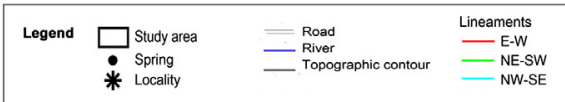

(c)

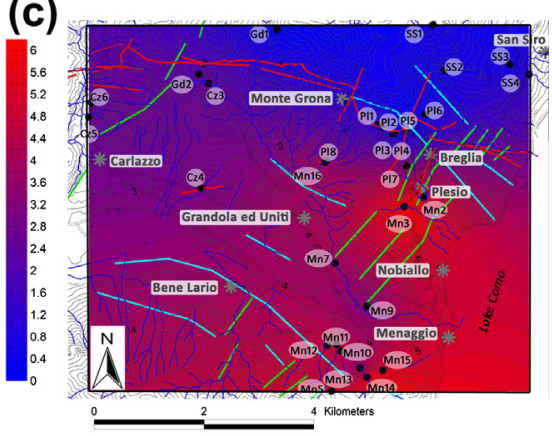

Fig. 6. Conductivity (a), $\mathrm{Si}(\mathrm{b})$ and $\mathrm{HCO}_{3}^{-}$(c) contourings.

(a)

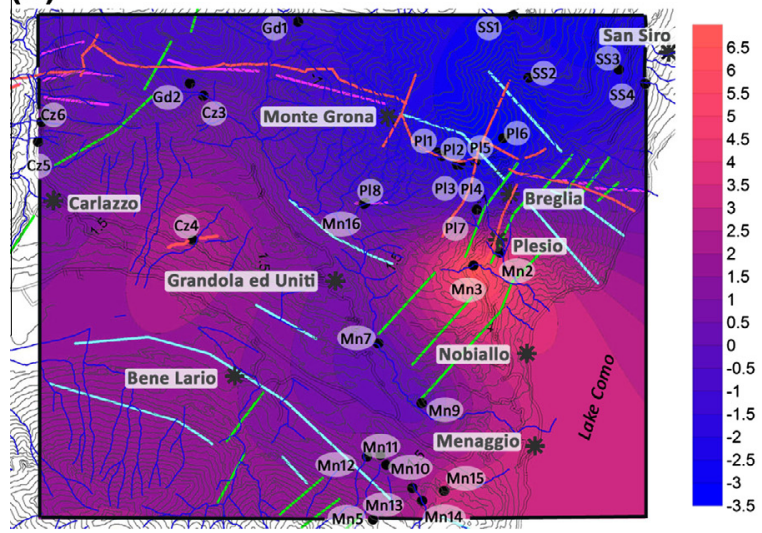

(b)

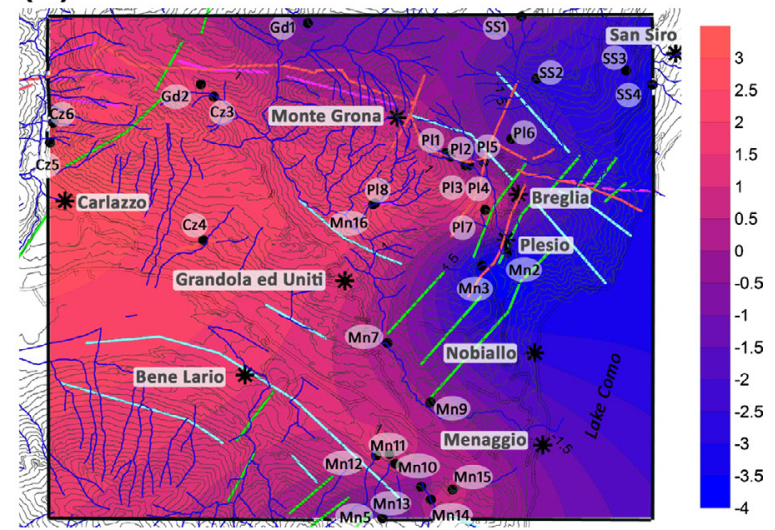

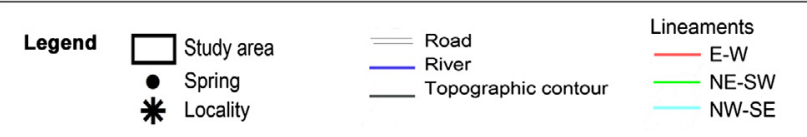

Fig. 7. PC1-scores (a) and PC2-scores (b) contourings.

tems appear to be associated with the Grona and Breglia faults. The area of Plesio is characterized by the presence of E-W, NE-SW and NW-SE lineaments and by the NE-SW directed measured fracture system, which is oriented like the Breglia fault.

\subsection{Chemical data}

The hydrochemical data are shown in Table 2. Physical chemical parameters vary in the following ranges: temperature from $7.9^{\circ} \mathrm{C}$ (Mn13 and $\mathrm{Pl} 2$ ) to $11.5^{\circ} \mathrm{C}$ (Mn9 and $\left.\mathrm{Cz} 4\right) ; \mathrm{pH}$ from $6.02(\mathrm{Gd} 1)$ to 8.17 (Mn16); EC from $39.4 \mu \mathrm{S} / \mathrm{cm}$ (Cz5) to $607 \mu \mathrm{S} / \mathrm{cm}$ (Mn3). Chebotarev and triangular diagrams permitted the identification of three main types of water (Fig. 4): the first one (Mn5, Mn10, Mn11, Mn12, Mn13 and Mn14) is characterized by high contents of $\mathrm{HCO}_{3}^{-}$and $\mathrm{Ca}^{2+}$; the second one (Mn2, Mn3, Mn7, Mn9, Mn15, Mn16, Pl1, Pl2, Pl3, Pl7, Pl8, Cz3, Cz4, Cz5, Cz6 and Gd2) is $\mathrm{HCO}_{3}^{-}$, $\mathrm{Ca}^{2+}$ and $\mathrm{Mg}^{2+}$ enriched; the third one (Pl4, Pl5, Pl6, SS1, SS2, SS3 and SS4) is characterized by high contents of $\mathrm{HCO}_{3}^{-}$and $\mathrm{Ca}^{2+}$ and an increase in $\mathrm{SO}_{4}^{2-}$ and/or $\mathrm{Na}^{+}+\mathrm{K}^{+}$compared with the others. The water of $\mathrm{Gd} 1$ spring is $\mathrm{SO}_{4}^{2-}$ and $\mathrm{Na}^{+}+\mathrm{K}^{+}$enriched; this sample differs from the main types of water previously described.
An exploratory PCA analysis was performed on the dataset to obtain additional features in the investigated springs (Wold et al., 1987; Brereton, 2007). Principal Components one to four (labelled in Fig. 5 as PC1, PC2, PC3 and PC4), accounting for $78 \%$ of the data variance, were considered for the interpretation (following PCs did not add relevant information). Bidimensional score and loading plots were interpreted. The two first principal components account for 52\% (PC1 32\%, PC2 20\%) of the total information (Fig. 5a and b). Loading plot PC1 vs. PC2 shows a correlation between dissolved silica and As (labelled as Si and As), which occupy the lower left part of the diagram. They are inversely correlated to $\mathrm{Ca}^{2+}, \mathrm{Mg}^{2+}, \mathrm{HCO}_{3}^{-}$, which lie in the opposite quadrant (Fig. 5b). In the score plot (Fig. 5a), samples seem to lie homogeneously around the model centre, but Mn2 and Mn3 assume a peculiar position at high positive values of PC1 and negative values of PC2. This could be ascribed to high levels of $\mathrm{Na}^{+}, \mathrm{K}^{+}$and $\mathrm{B}$, as emerges looking at the loading plot. Studying the score plot for better insight, a trend in the samples emerges.

The study of the second and third principal components ( $\mathrm{PC} 2$ 20\%-PC3 18\%) gives more interesting information concerning Mn2 and Mn3 spring samples. In the score plot PC2 vs. PC3 (Fig. 5c), they are located near the SS2, SS3 and SS4 springs; this 

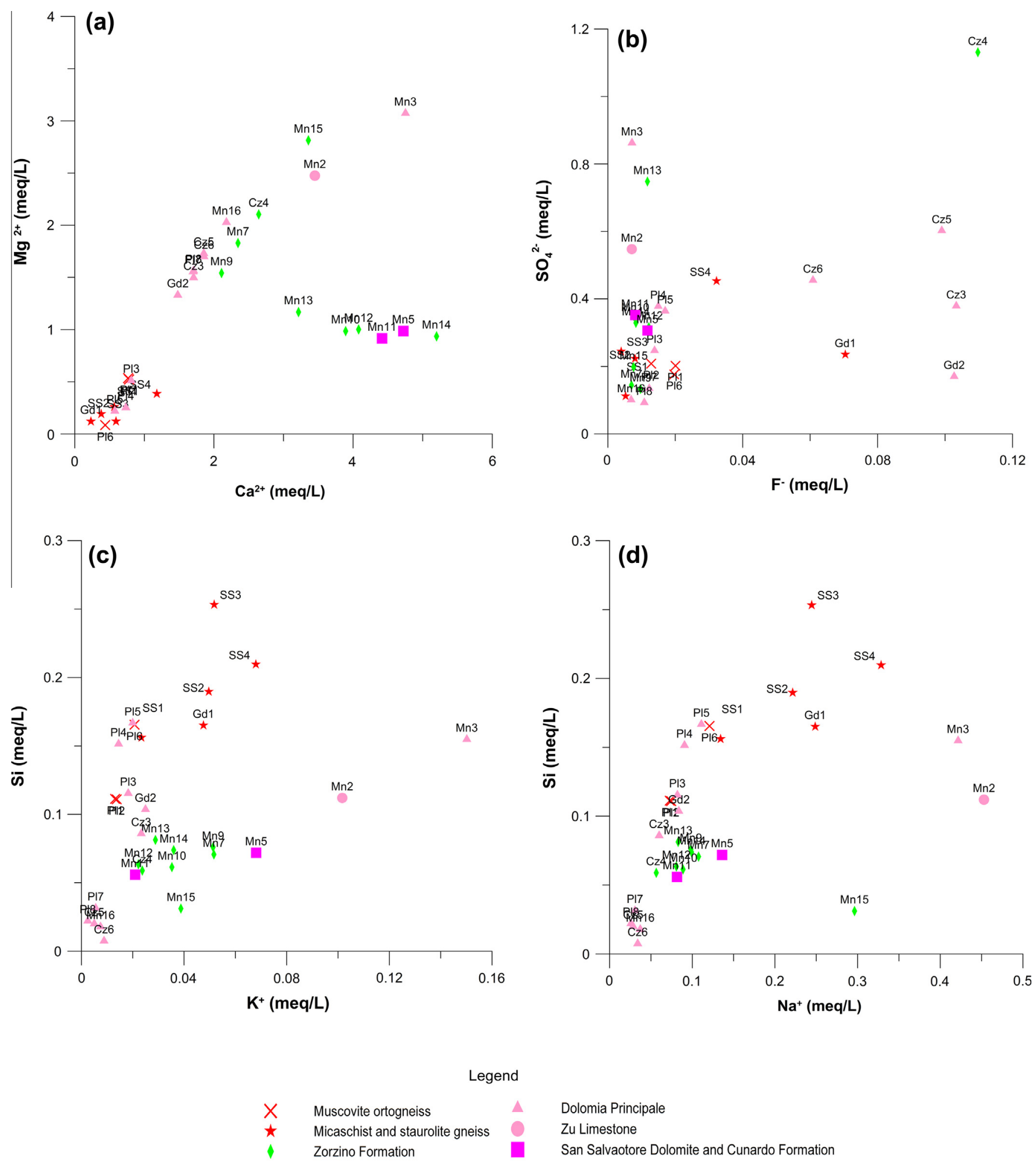

Fig. 8. Bivariate plots of $\mathrm{Ca}^{2+}$ vs. $\mathrm{Mg}^{2+}$ (a), $\mathrm{F}^{-}$vs. $\mathrm{SO}_{4}^{2}$ (b), $\mathrm{K}^{+}$vs. $\mathrm{Si}(\mathrm{c})$ and $\mathrm{Na}^{+}$vs. $\mathrm{Si}(\mathrm{d})$.

position depends on the dissolved silica and As contents, as emerges from the loading plot PC2 vs. PC3 (Fig. 5d). More interesting information concerns the location of the $\mathrm{Cz} 4$ spring in the upper right zone of the diagram (Fig. 5c) that is due to the Rn $\left({ }^{222} \mathrm{Rn}\right)$ and $\mathrm{F}^{-}$contents. PC3 vs. PC4 score plots (Fig. 5e and f) confirm the linking of the $\mathrm{Cz} 4$ spring with $\mathrm{Rn}$ and $\mathrm{F}^{-}$; furthermore, these PCs highlight an enrichment in $\mathrm{Ca}^{2+}$ for springs located in the left lower quadrant (Mn5, Mn10, Mn11, Mn12, Mn13 and Mn14; Fig. 5e).
The score values for each sample on PC1 and PC2 were also employed to draw a contour plot, the results of which are discussed in the following section.

\section{Discussion}

Hydrochemical data, derived from Chebotarev triangular diagrams and PCA, were compared with the lithology of springs and 
geostructural data in order to characterize the complex groundwater systems of the study area. To accurately identify these flow paths, specific bivariate plots and contouring were implemented. The spatial distribution of $\mathrm{EC}, \mathrm{Si}, \mathrm{HCO}_{3}^{-}, \mathrm{PC} 1$ and $\mathrm{PC} 2$ values can be observed in Figs. 6 and 7. EC (Fig. 6a) and $\mathrm{HCO}_{3}^{-}$(Fig. 6c) values are high in the central and southern part of the study area (south of the Grona fault, Fig. 1), in accordance with the presence of carbonate rocks. The analysis of the spatial distribution of Si (Fig. 6b) shows two areas with high concentrations in the NE part of the study area and between Plesio and Nobiallo. The first one is the region of the crystalline basement (Celico, 1986; Faure, 1996). In contrast, the second one is atypical because in this area only carbonate rocks outcrop. The spatial distribution of the PC1 values (Fig. 7a) shows conditions similar to those illustrated in the EC and $\mathrm{HCO}_{3}^{-}$contours. However, it highlights a particular area near the Mn7 and Mn9 springs, where there is a plume of low values of PC1 ascribable to the drainage effect of the Breglia fault, which carries water from the crystalline basement. This effect is also showed for the Mn2 and Mn3 springs in the PC2 contour (Fig. 7b).

For a better characterization of some particular leaching conditions (Fig. 8), the following bivariate plots were used: $\mathrm{F}^{-} \mathrm{vs} . \mathrm{SO}_{4}^{2}$, to evaluate the leaching of an evaporite body $\left(\mathrm{SO}_{4}^{2-}\right)$ and, generally, the depth of circulation $\left(\mathrm{F}^{-}\right)$; $\mathrm{Na}^{+}$vs. Si and $\mathrm{K}^{+} \mathrm{vs}$. Si, to study the water interaction with the crystalline basement; and $\mathrm{Ca}^{2+}$ vs. $\mathrm{Mg}^{2+}$, to discriminate the waters that leach dolomite rocks or limestone. The matching of the results given by all plots allows the identification of three main groups of water in agreement with the rocks in which they arise. Group I (Mn5, Mn10, Mn11, Mn12, $\mathrm{Mn} 13$ and $\mathrm{Mn} 14)$ is characterized by $\mathrm{Ca}^{2+}, \mathrm{HCO}_{3}^{-}$and $\mathrm{Mg}^{2+}$ enrichment with $\mathrm{Mg}^{2+} / \mathrm{Ca}^{2+}$ ratios less than $1\left(\mathrm{Ca}^{2+}>\mathrm{Mg}^{2+}\right)$; these waters flow in limestone. Group II (Mn16, Pl3, Pl4, Pl5 Pl7, Pl8, Cz3, Cz5, $\mathrm{Cz} 6$ and $\mathrm{Gd} 2$ ) is enriched in $\mathrm{HCO}_{3}^{-}$and $\mathrm{Ca}^{2+}$ and $\mathrm{Mg}^{2+}$ with $\mathrm{Ca} / \mathrm{Mg}$ ratios near 1 and circulates in dolomite rocks. Group III (Pl6, SS1, SS2, SS3 and SS4) is characterized by a decrease of $\mathrm{Ca}^{2+}$ and $\mathrm{Mg}^{2+}$ content, an increase of $\mathrm{Na}^{+}+\mathrm{K}^{+}$and a high $\mathrm{Si} / \mathrm{EC}$ ratio; this group flows in the basement rocks.

Some peculiarities were noted, specifically in the Mn2, Mn3, Mn7, Mn9, Mn15, Cz4, Pl1, Pl2 and Gd1 springs (see Tables 1 and 2). Springs $\mathrm{Mn} 2$ and $\mathrm{Mn} 3$ are located near Plesio in glacial deposits that cover dolomite rocks (Fig. 1). Their hydrogeochemistry shows behaviour typical of waters that have leached dolomite rocks $\left(\mathrm{Ca}^{2+}\right.$ vs. $\mathrm{Mg}^{2+}$ ratio near 1 and $\mathrm{HCO}_{3}^{-}$enrichment; Celico, 1986; Faure, 1996; Civita, 2005), but the PCA analysis (Fig. 5) and $\mathrm{Na}^{+}$vs. Si (Fig. 8d) and $\mathrm{K}^{+}$vs. Si bivariate plots (Fig. 8c) show B, $\mathrm{Na}^{+}, \mathrm{K}^{+}$, As and $\mathrm{Si}$ anomalies. The $\mathrm{B}$ anomaly is generated by the low value (proximal to LOD) of this element in the water that does not permit significant discrimination. The $\mathrm{Na}^{+}, \mathrm{K}^{+}$, As and Si anomalies may result from water circulation in glacial deposits and then in dolomite rocks, or from deeper circulation that intersects the crystalline basement (Celico, 1986; Faure, 1996; Banks et al., 1998; Civita, 2005) to the north of the Grona fault. The first case is excluded because the moderately high EC values (Mn2 $472 \mu \mathrm{S} / \mathrm{cm}$; Mn3 $607 \mu \mathrm{S} / \mathrm{cm}$; Table 2; Nordstrom et al., 1989; Faure, 1996; Civita, 2005) suggest deeper circulation. The second case is more plausible: the role of the Breglia fault system, as a drain, generates mixing between the water that circulates in the crystalline basement $\left(\mathrm{Na}^{+}, \mathrm{K}^{+}\right.$, As and Si enrichment) in the north and the water that circulates in dolomite rocks $\left(\mathrm{Ca}^{2+} \mathrm{Mg}^{2+}\right.$ and $\mathrm{HCO}_{3}^{-}$enrichment) in the south. The second case is also confirmed by geostructural analysis and remote sensing that show a persistent fracture system oriented NE-SW near the Mn2 and Mn3 springs (Figs. 1 and 3) and by $\mathrm{Si}$ contouring, which shows a plume in this area.

The role played by the Breglia fault system in groundwater circulation is also demonstrated by the Mn7 and Mn9 springs. They rise in bituminous limestone of the Zorzino Formation (Table 1), but their waters show chemical features typical of circulation in dolomite rocks: the $\mathrm{Ca} / \mathrm{Mg}$ ratios are close to one (Fig. 8a). This type of anomaly could be due to the fault promoting the rise of deep waters that leached dolomite of Dolomia Principale; the remote sensing and the structural analysis, in fact, also highlight the presence of the Breglia Fault system in this area (Fig. 3).

The $\mathrm{Cz} 4$ spring rises in bituminous limestone of the Zorzino Formation (Table 1 ), but shows a $\mathrm{Ca}^{2+}, \mathrm{Mg}^{2+}$ and $\mathrm{HCO}_{3}^{-}$enrichment (circulation in dolomite). The remote sensing (Fig. 3 ) highlights an $\mathrm{E}-\mathrm{W}$ lineament that suggests the presence of a fault, confirmed also by the ${ }^{222} \mathrm{Rn}$ concentration $(105 \mathrm{~Bq} / \mathrm{L}$; Table 2 ; Banks et al., 1998; Pascale et al., 2011). This fault brings up water from the underlying Dolomia Principale. The hypothesis of deep circulation is also supported by the $\mathrm{F}^{-}$anomaly (Figs. $5 \mathrm{c}$ and $\mathrm{d}$, and $8 \mathrm{~b}$ ) and $\mathrm{SO}_{4}^{2-}$ (Fig. $\left.8 \mathrm{~b}\right)$ and EC ( $439 \mu \mathrm{S} / \mathrm{cm}$ ) values (Table 2 and Fig. 6a; Celico, 1986; Nordstrom et al., 1989; Banks et al., 1998; Salih et al., 2004; Civita, 2005; Kim and Jeong, 2005). In particular, the high $\mathrm{SO}_{4}^{2-}$ concentration could be ascribed to the leaching of Dolomia Principale evaporite bodies.

The Mn15 spring rises in bituminous limestone of the Zorzino Formation (Table 1), but shows a $\mathrm{Ca}^{2+}, \mathrm{Mg}^{2+}$ and $\mathrm{HCO}_{3}^{-}$enrichment (circulation in dolomite). The remote sensing and geological setting (Figs. 1 and 3), in this case, do not reveal the presence of a fault, but the ${ }^{222} \mathrm{Rn}$ concentration $(40.2 \mathrm{~Bq} / \mathrm{L}$; Table 2; Banks et al., 1998; Pascale et al., 2011), similar to the Cz4 spring, suggests

Table 1

Lithology location of springs.

\begin{tabular}{|c|c|c|c|}
\hline Name & Lithology & Name & Lithology \\
\hline Menaggio springs & & Plesio springs & \\
\hline Mn2 & Glacial deposit & $\mathrm{Pl} 1$ & Muscovite orthogneiss \\
\hline Mn3 & Glacial deposit & $\mathrm{Pl} 2$ & Muscovite orthogneiss \\
\hline Mn5 & Limestone (Zu Limestone) & $\mathrm{Pl} 3$ & Dolomite (Dolomia Principale) \\
\hline Mn7 & Bituminous limestone (Zorzino Formation) & $\mathrm{Pl} 4$ & Dolomite (Dolomia Principale) \\
\hline Mn9 & Bituminous limestone (Zorzino Formation) & $\mathrm{Pl} 5$ & Glacial deposit \\
\hline $\operatorname{Mn} 10$ & Bituminous limestone (Zorzino Formation) & Pl6 & Glacial deposit \\
\hline Mn11 & Limestone (Zu Limestone) & Pl7 & Glacial deposit \\
\hline Mn12 & Bituminous limestone (Zorzino Formation) & Pl8 & Dolomite (Dolomia Principale) \\
\hline Mn13 & Bituminous limestone (Zorzino Formation) & Grandola ed Uniti springs & \\
\hline Mn15 & Bituminous limestone (Zorzino Formation) & Gd1 & Glacial deposit \\
\hline Mn16 & Bituminous limestone (Zorzino Formation) & Gd2 & dolomite (Dolomia Principale) \\
\hline Carlazzo springs & & San Siro springs & \\
\hline $\mathrm{Cz} 3$ & Dolomite (Dolomia Principale) & SS1 & Micaschist and staurolite gneiss \\
\hline $\mathrm{Cz} 4$ & Bituminous limestone (Zorzino Formation) & SS2 & Glacial deposit \\
\hline $\mathrm{Cz} 5$ & Dolomite (Dolomia Principale) & SS3 & Micaschist and staurolite gneiss \\
\hline $\mathrm{Cz} 6$ & Dolomite (Dolomia Principale) & SS4 & Micaschist and staurolite gneiss \\
\hline
\end{tabular}


Table 2

Geochemical data of studied groundwaters.

\begin{tabular}{|c|c|c|c|c|c|c|c|c|c|c|c|c|c|c|c|c|c|c|c|c|}
\hline $\begin{array}{l}\text { Spring } \\
\text { ID }\end{array}$ & $\begin{array}{l}\text { Temp. } \\
\left({ }^{\circ} \mathrm{C}\right)\end{array}$ & $\mathrm{pH}$ & $\begin{array}{l}\text { Cond. } \\
(\mathrm{mS} / \mathrm{cm})\end{array}$ & $\begin{array}{l}\text { Radon } \\
(\mathrm{Be} / \mathrm{L})\end{array}$ & $\begin{array}{l}\mathrm{SiO}_{2} \\
(\mathrm{mg} / \mathrm{L})\end{array}$ & $\begin{array}{l}\mathrm{HCO}_{3}^{-} \\
(\mathrm{meq} / \mathrm{L})\end{array}$ & $\begin{array}{l}\mathrm{F}^{-}(\mathrm{meq} / \\
\mathrm{L})\end{array}$ & $\begin{array}{l}\mathrm{Cl}^{-}(\mathrm{meq} / \\
\mathrm{L})\end{array}$ & $\begin{array}{l}\mathrm{NO}_{3}^{-} \\
\text {(meq/ } \\
\mathrm{L} \text { ) }\end{array}$ & $\begin{array}{l}\mathrm{SO}_{4}^{2-} \\
(\mathrm{meq} / \mathrm{L})\end{array}$ & $\begin{array}{l}\mathrm{Na}^{+} \\
\text {(meq/ } \\
\mathrm{L})\end{array}$ & $\begin{array}{l}\mathrm{K}^{+} \\
(\text {meq/ } \\
\mathrm{L})\end{array}$ & $\begin{array}{l}\mathrm{Ca}^{2+} \\
(\mathrm{meq} / \\
\mathrm{L})\end{array}$ & $\begin{array}{l}\mathrm{Mg}^{2+} \\
(\mathrm{meq} / \mathrm{L})\end{array}$ & $\begin{array}{l}\mathrm{NH}_{4}^{+} \\
\text {(meq/ } \\
\text { L) }\end{array}$ & $\begin{array}{l}\mathrm{Li} \\
(\mathrm{mg} / \\
\mathrm{L})\end{array}$ & $\begin{array}{l}\text { B } \\
(\mathrm{mg} / \\
\mathrm{L})\end{array}$ & $\begin{array}{l}\text { Mn } \\
(\mathrm{mg} / \\
\mathrm{L})\end{array}$ & $\begin{array}{l}\mathrm{Fe} \\
(\mathrm{mg} / \\
\mathrm{L})\end{array}$ & $\begin{array}{l}\text { As } \\
(\mathrm{mg} / \\
\mathrm{L})\end{array}$ \\
\hline Mn2 & 9.8 & 6.84 & 472 & 26.5 & 3.15 & 5.28 & 0.007 & 0.21 & 0.29 & 0.55 & 0.45 & 0.10 & 3.45 & 2.48 & 0.058 & 0.60 & 27.5 & $<\mathrm{LOD}$ & 65 & 13 \\
\hline Mn3 & 10.5 & 6.87 & 607 & 10.6 & 4.36 & 5.98 & 0.007 & 0.30 & 0.54 & 0.86 & 0.42 & 0.15 & 4.75 & 3.07 & 0.086 & 1.35 & 28.0 & $<$ LOD & 84 & 5.3 \\
\hline Mn5 & 9.7 & 6.67 & 409 & 4.21 & 2.02 & 5.03 & 0.012 & 0.024 & 0.093 & 0.31 & 0.14 & 0.068 & 4.72 & 0.99 & 0.114 & 2.43 & 14.0 & 0.049 & 101 & $<$ LOD \\
\hline Mn7 & 11.3 & 7.66 & 350 & - & 1.99 & 3.87 & 0.007 & 0.058 & 0.11 & 0.14 & 0.11 & 0.052 & 2.34 & 1.83 & 0.083 & 0.076 & 3.53 & 0.18 & 49.5 & 6.2 \\
\hline Mn9 & 11.5 & 7.99 & 308 & 12.0 & 2.14 & 3.27 & 0.010 & 0.031 & 0.10 & 0.13 & 0.098 & 0.051 & 2.11 & 1.54 & 0.101 & 0.17 & 2.09 & 0.18 & 47.6 & 4.2 \\
\hline Mn10 & 8.4 & 7.30 & 412 & 11.6 & 1.73 & 4.61 & 0.008 & 0.033 & 0.11 & 0.34 & 0.089 & 0.035 & 3.89 & 0.99 & 0.062 & 0.94 & 9.56 & $<$ LOD & 887 & 0.14 \\
\hline Mn11 & 8.3 & 7.54 & 417 & 23.8 & 1.57 & 4.64 & 0.008 & 0.036 & 0.11 & 0.35 & 0.081 & 0.021 & 4.42 & 0.92 & 0.092 & 1.16 & 8.94 & 0.047 & 986 & 0.21 \\
\hline Mn12 & 8.0 & 7.44 & 406 & 11.6 & 1.79 & 4.63 & 0.012 & 0.028 & 0.11 & 0.32 & 0.081 & 0.022 & 4.08 & 1.00 & 0.068 & 1.05 & 9.87 & 0.070 & 922 & 0.18 \\
\hline Mn13 & 7.9 & 6.55 & 354 & 5.82 & 2.29 & 3.34 & 0.012 & 0.025 & 0.098 & 0.75 & 0.083 & 0.029 & 3.22 & 1.17 & 0.10 & 5.62 & 19.1 & 0.11 & 802 & 0.082 \\
\hline Mn14 & 8.6 & 7.20 & 379 & 18.0 & 2.08 & 5.49 & 0.008 & 0.027 & 0.087 & 0.33 & 0.099 & 0.036 & 5.20 & 0.94 & 0.11 & 2.12 & 13.4 & 0.078 & 1204 & 0.14 \\
\hline Mn15 & 8.1 & 7.51 & 469 & 40.2 & 0.88 & 5.31 & 0.008 & 0.34 & 0.17 & 0.20 & 0.30 & 0.039 & 3.36 & 2.81 & 0.12 & 0.15 & 1.57 & $<$ LOD & 843 & 0.47 \\
\hline Mn16 & 11.0 & 8.17 & 339 & 3.19 & 0.51 & 3.83 & 0.007 & 0.022 & 0.071 & 0.10 & 0.037 & 0.007 & 2.18 & 2.03 & 0.076 & 0.11 & 2.00 & 0.20 & 594 & 0.73 \\
\hline Pl1 & 8.2 & 7.66 & 147 & 32.1 & 3.13 & 1.19 & 0.020 & 0.038 & 0.033 & 0.20 & 0.073 & 0.013 & 0.78 & 0.52 & 0.017 & 0.29 & 1.46 & 0.059 & 217 & 5.2 \\
\hline $\mathrm{Pl} 2$ & 7.9 & 8.04 & 150 & 5.24 & 3.12 & 1.26 & 0.013 & 0.030 & 0.045 & 0.21 & 0.074 & 0.014 & 0.77 & 0.54 & 0.033 & 0.31 & 1.52 & 0.081 & 192 & 6.0 \\
\hline Pl3 & 8.4 & 7.80 & 153 & - & 3.25 & 1.21 & 0.014 & 0.029 & 0.064 & 0.25 & 0.082 & 0.018 & 0.81 & 0.51 & 0.038 & 0.33 & 2.18 & 0.12 & 225 & 5.7 \\
\hline Pl4 & 8.9 & 7.67 & 133 & 49.2 & 4.26 & 0.68 & 0.015 & 0.022 & 0.022 & 0.38 & 0.091 & 0.014 & 0.73 & 0.25 & 0.011 & 0.74 & 2.29 & 0.12 & 224 & 25 \\
\hline Pl5 & 9.0 & 7.26 & 101 & 49.7 & 4.69 & 0.56 & 0.017 & 0.026 & 0.039 & 0.36 & 0.11 & 0.020 & 0.57 & 0.22 & 0.034 & 0.94 & 2.36 & 0.19 & 141 & 6.7 \\
\hline Pl6 & 9.2 & 7.27 & 58.5 & 103 & 4.65 & 0.50 & 0.020 & 0.041 & 0.030 & 0.18 & 0.12 & 0.021 & 0.44 & 0.086 & 0.028 & 0.70 & 1.73 & 0.12 & 102 & 27 \\
\hline Pl7 & 10.8 & 7.61 & 219 & 16.4 & 0.89 & 3.29 & 0.012 & 0.033 & 0.10 & 0.13 & 0.031 & 0.006 & 1.70 & 1.56 & 0.027 & 0.22 & 2.33 & 0.16 & 494 & 0.88 \\
\hline Pl8 & 10.5 & 7.44 & 327 & 19.0 & 0.62 & 3.34 & 0.011 & 0.016 & 0.076 & 0.09 & 0.026 & 0.002 & 1.71 & 1.56 & 0.023 & 0.22 & 2.62 & 0.13 & 472 & 0.46 \\
\hline SS1 & 9.0 & 7.46 & 86.0 & 6.17 & 4.39 & 0.68 & 0.005 & 0.034 & 0.046 & 0.11 & 0.13 & 0.023 & 0.59 & 0.12 & 0.048 & 1.25 & 1.20 & $<$ LOD & 27 & 1.8 \\
\hline SS2 & 11.0 & 6.80 & 86.0 & 64.2 & 5.34 & 0.74 & 0.008 & 0.051 & 0.031 & 0.22 & 0.22 & 0.050 & 0.57 & 0.26 & 0.050 & 5.13 & 2.16 & 0.13 & 30 & 11 \\
\hline SS3 & 10.8 & 7.00 & 75.0 & 18.5 & 7.12 & 0.62 & 0.004 & 0.032 & 0.033 & 0.24 & 0.24 & 0.052 & 0.38 & 0.19 & 0.059 & 3.11 & 2.06 & 0.21 & 69 & 4.1 \\
\hline SS4 & 13.0 & 7.33 & 195 & 13.9 & 5.90 & 1.24 & 0.032 & 0.049 & 0.055 & 0.45 & 0.33 & 0.068 & 1.18 & 0.39 & 0.049 & 3.82 & 2.77 & 0.18 & 13 & 20 \\
\hline Cz3 & 8.1 & 7.25 & 257 & 29.3 & 2.42 & 2.49 & 0.10 & 0.20 & 0.38 & 0.38 & 0.060 & 0.023 & 1.71 & 1.50 & 0.006 & 0.32 & 2.31 & 0.067 & 384 & 1.1 \\
\hline $\mathrm{Cz} 4$ & 11.5 & 6.84 & 439 & 105 & 1.66 & 3.02 & 0.11 & 0.25 & 0.55 & 1.13 & 0.056 & 0.024 & 2.64 & 2.10 & 0.017 & 0.21 & 7.97 & 0.11 & 637 & 0.59 \\
\hline Cz5 & 11.4 & 7.14 & 39.4 & 73.8 & 0.57 & 2.41 & 0.099 & 0.15 & 0.21 & 0.60 & 0.028 & 0.005 & 1.85 & 1.73 & 0.024 & 0.17 & 2.01 & 0.17 & 484 & 0.36 \\
\hline Cz6 & 10.4 & 7.37 & 291 & - & 0.21 & 2.81 & 0.061 & 0.14 & 0.31 & 0.46 & 0.034 & 0.009 & 1.86 & 1.70 & 0.042 & 0.20 & 2.01 & 0.11 & 461 & 0.24 \\
\hline Gd1 & 8.6 & 6.02 & 51.9 & 25.6 & 4.64 & 0.13 & 0.070 & 0.11 & 0.16 & 0.24 & 0.25 & 0.048 & 0.23 & 0.12 & 0.072 & 1.00 & 1.97 & 0.018 & 51 & 2.4 \\
\hline $\mathrm{Gd} 2$ & 8.6 & 6.42 & 288 & - & 2.92 & 2.22 & 0.10 & 0.097 & 0.18 & 0.17 & 0.084 & 0.025 & 1.48 & 1.33 & 0.017 & 0.43 & 2.72 & 0.16 & 436 & 1.5 \\
\hline
\end{tabular}

the presence of a fault that brings water from the overlying Conchodon Dolomite.

The Pl1 and Pl2 springs lie in muscovite orthogneiss (Table 1), but reflect a dolomite water chemistry $\left(\mathrm{Ca}^{2+}, \mathrm{Mg}^{2+}\right.$ and $\mathrm{HCO}_{3}^{-}$ enrichment). These springs are located to the north of the Grona Fault system in muscovite orthogneiss near the contact with Dolomia Principale (Fig. 1). The geostructural analysis shows strong rock fracturing (Fig. 3) that conveys the dolomite water to the north, stepping over the Grona Fault. This circulation generates mixing between crystalline and dolomite water. The mixing is also confirmed by the anomaly for As and ${ }^{222} \mathrm{Rn}$ (Fig. 5a and b) of Pl1, $\mathrm{Pl} 2$.

The Gd1 spring shows a short circuit (EC: $51.90 \mu \mathrm{S} / \mathrm{cm}$; Table 2; Celico, 1986; Civita, 2005) that leaches heterogeneous glacial deposits. This spring is enriched in $\mathrm{SO}_{4}^{2-}, \mathrm{Cl}^{-}, \mathrm{Ca}^{2+}$ and $\mathrm{Na}^{+}$: the $\mathrm{SO}_{4}^{2-}$ and $\mathrm{Ca}^{2+}$ value is due to interaction with gypsum deriving from freezing/thawing of the permafrost active layer in the past; $\mathrm{Cl}^{-}$and $\mathrm{Na}^{+}$result from the leaching of clay minerals.

\section{Conclusions}

This study demonstrates the relevance of a multidisciplinary investigation to obtain a complete picture of the groundwater systems in a complex of mountain aquifers. They are controlled by the tectonic setting, making understanding of their flow path extremely difficult when outcrops are missing. Hydrochemical data play a major role in circulation tracing. The groundwater system of Lake Como was investigated using geostructural, chemical and chemometric analyses. The geostructural data, in agreement with the remote sensing, show three main fracture systems (E-W, NE-SW and NW-SE); they are related to Grona and Breglia fault systems. The hydrochemistry (ground water chemistry and PCA) allowed identi- fication of waters that leach limestones, dolomite and crystalline rocks.

The matching of hydrochemical and geostructural information explains the role played by faults in water circulation. In particular, the Mn2 and Mn3 springs show mixing between the sub-surface water that leaches dolomite rocks, and deep water that circulates in the crystalline basement, brought up by the Breglia fault. The role played by this fault system in groundwater circulation is also evident for the Mn7 and Mn9 springs that rise in the Zorzino Formation (limestone); the Breglia fault permits the rise of deep water that leaches the underlying Dolomia Principale. The occurrence of the fault is revealed by hydrochemical data and remote sensing analysis, whereas the geostructural survey cannot give information because of the lack of outcrops. Similarly, the Grona fault plays a role on drainage in the proximity of the Pl1 and Pl2 springs. They are in muscovite orthogneiss but reflect a dolomite water chemistry. The strong rock fracturing conveys the dolomite water to the north, stepping over the Grona Fault. The power of the multidisciplinary approach is also confirmed by study of the Cz4 and Mn15 springs. This approach permitted understanding the groundwater system and identifivation of fault systems not detectable with a geostructural survey. The use of only geostructural or hydrochemical methods in complex mountain aquifers is not sufficient to understand the groundwater flow paths; the relationship of water circulation with the fault and the fracture systems may only be assessed by a multidisciplinary approach. In this way, the alignment of the area can be clearly identified and spring waters in mountain areas better exploited.

\section{Acknowledgments}

We would like to thank the Carlazzo, Grandola ed Uniti, Menaggio and Plesio municipalities for their assistance. We are particu- 
larly grateful to two anonymous reviewers and the Associate Editor Professor Ian Cartwright for their precious and constructive comments. Nancy Mammi is thanked for the English corrections. Dr S. Terrana and Dr R. Gambillara contributed equally to this work.

\section{References}

Agterberg, F.P., 1974. Geomathematics, Mathematical Background and Geo-Science Applications. Elsevier Scientific Publishing Company, Amsterdam.

Allasinaz, A., 1968. Il Carnico della Lombardia occidentale. Riv. Ital. Paleontol. Stratigr. 74, 1912-1920.

Banks, D., Frengstad, U.B., Midtgard, A.K., Krog, J.R., Strand, T., 1998. The chemistry of Norwegian groundwaters: I. The distribution of radon, major and minor elements in 1604 crystalline bedrock groundwaters. Sci. Total Environ. 222, 7191.

Belloni, S., Cojazzi, F., 1985. Variazioni delle precipitazioni in Lombardia nel cinquantennio 1921-1970. Acqua Aria 7, 639-646.

Bernoulli, D., Heitzmann, P., Zingg, A., 1990. Central and SouthernAlps in southern Switzerland: tectonic evolution and first results of reflection seismics. In: Roure, F., Heitmzann, P.E., Polino, R. (Eds.), Deep Structure of the Alps, vol. spec 1. Società Geologica Italiana, pp. 289-302.

Bertotti, G., 1991. Early mesozoic extension and alpine shortening in the western southern alps: the geology of the area between lugano and Menaggio (lombardy, northern italy). Memor. Soc. Geol. 43, 17-123.

Boriani, A., Colombo, C., 1979. Gli gneiss chiari tra la Valsesia e il Lago di Como. Rend. Soc. Ital. Mineral. Petrog. 35, 299-312.

Boriani, A., Bigioggero, B., Origoni Giobbi, E., 1977. Metamorphism, tectonic evolution and tentative stratigraphy of the "Serie dei laghi", Geologic Map of the Verbania Area (Norther Italy). Memor. Soc. Geol. Padova 32, 1-26.

Brereton, R.G., 2007. Applied Chemometrics For Scientists. Wiley-Blackwell, Chicester.

Casati, P., 1964. Il Trias in Lombardia (studi geologici e paleontologici). VI. Osservazioni stratigrafiche sull'Infraretico delle Prealpi bergamasche. Riv. Ital. Paleont. Stratigrafia 70, 447-465.

Celico, P., 1986. Prospezioni Idrogeologiche II. Liguori, Naples.

Chebotarev, I.I., 1952. Hydrological and thermal aspect of petroleum occurence. Bull. Am. Assoc. Petrol. Geolog. 36.

Civita, M., 2005. Idrogeologia Applicata e Ambientale. CEA, Milan.

Dassi, L., 2011. Investigation by multivariate analysis of groundwater composition in a multilayer aquifer system from North Africa: a multi-tracer approach. Appl. Geochem. 26, 1386-1398.

Dossi, C., Recchia, S., Fusi, A., 2000. Automated chloride analysis in catalytic science: a low-cost hardware and software implementation. Fres. J. Anal. Chem. 367, 416-421.

Earman, S., McPherson, Brian J.O.L., Phillips, F.M., Ralser, S., Herrin, J.M., Broska, J., 2008. Tectonic influences on ground water quality: insight from complementary methods. Groundwater 46, 351-371.

Eaton, T.T., 2006. On the importance of geological heterogeneity for flow simulation. Sed. Geol. 184, 187-201.

Farabegoli, E., De Zanche, V., 1984. A revision of the Anisian stratigraphy in the western Southern Alps, west of Lake Como. Memor. Soc. Geol. Padova 36, 391401.

Faure, G., 1996. Principles and Applications of Geochemistry. Macmillan, New York.

Fjeld, R.A., Montague, K.J., Haapala, M.H., Kotrappa, P., 1994. Field test of Electrets Ion Chamber for environmental monitoring. Health Phys. 66, 147-154.

Francani, V., 1986. La circolazione idrica degli ammassi rocciosi del Lario. Memor. Soc. Geol. Ital. 32, 167-178.

Gaetani, M., Gianotti, R., Jadoul, F., Ciarapica, G., Birilli, S., Lualdi, A., Passeri, L., Pellegrini, M., Tannoia, G., 1986. Carbonifero superiore, Permiano e Triassico nell'area Lariana. Memor. Soc. Geol. Ital. 32, 5-48.

Gambillara, R., 2005. Caratterizzazione strutturale e geochimica del sistema di alimentazione idrica profonda nell'area del lago di Como (settore settentrionale e occidentale). PhD Thesis, Universita degli Studi dell'Insubria.

Ghasemizadeh, R., Hellweger, F., Butscher, C., Padilla, I., Vesper, D., Field, M., Alshawabkeh, A., in press. Review: groundwater flow and transport modeling of karst aquifers, with particular reference to the North Coast Limestone aquifer system of Puerto Rico. Hydrogeol. J.

Gianotti, R., 1984. Individuazione di un margine delimitante a Nord-Est il bacino del M. Generoso. Rend. Soc. Geol. Ital. 7, 7-8.

Gianotti, R., Tannoia, G., 1988. Elementi per una revisione stratigraficopaleontologica del Trias medio-superiore della regione compresa tra il Lario ed il Ceresio. Atti Ticinesi di Scienze della Terra 31, 434-445.

Goldscheider, N., Neukum, C., 2010. Fold and fault control on the drainage pattern of a double-karst-aquifer system, Winterstaude, Austrian Alps. Acta Carsol. 39, 173-186.
Hua, B., Yang, J., Deng, B., 2011. Groundwater quality. Water Environ. Res. 83, 1665 1682.

Isaaks, E.H., Srivastava, R.M., 1989. An Introduction to Applied Geostatistics. Oxford University Press, New York.

Kacaroglu, F., 1999. Review of groundwater pollution and protection in karst areas. Water Air Soil Pollut. 113, 337-356.

Kalin, V.O., Trumpy, D.M., 1977. Sedimentation und Palaotektonik in den westlichen Sudalpen: Zur triassich-jurassichen geschichte des Monte Nudo-Beckens. Eclogae Geologicae Helvetiae 70, 295-350.

Kim, K., Jeong, G.Y., 2005. Factors influencing natural occurrence of fluoride-rich groundwaters: a case study in the southeastern part of the Korean Peninsula. Chemosphere 58, 1399-1408.

Koonce, J.E., Yu, Z., Farnham, I.M., Stetzenbach, K.J., 2006. Geochemical interpretation of groundwater flow in the southern Great Basin. Geosphere 2, $88-101$.

Kotrappa, P., 2008. Long term stability of electrets used in electret ion chambers. J. Electrostat. 66, 407-409.

Kotrappa, P., Jesters, W.A., 1993. Electret ion chamber radon monitors measure dissolved ${ }^{222} \mathrm{Rn}$ in water. Health Phys. 64, 397-405.

Kotrappa, P., Dempsey, J.C., Hickey, J.R., Stieff, L.R., 1988. An electret passive environmental ${ }^{222} \mathrm{Rn}$ monitor based on ionization measurement. Health Phys. Soc. 54, 47-50.

Krige, D.G., 1951. A Statistical Approach to Some Mine Valuations and Allied Problems at the Witwatersrand. Master's Thesis, Univ. Witwatersrand.

Lachassagne, P., Wyns, R., Dewandel, B., 2011. The fracture permeability of Hard Rock Aquifers is due neither to tectonics, nor to unloading, but to weathering processes. Terra Nova 23, 145-161.

Legrand, H.E., Stringfield, V.T., 1973. Karst hydrology - a review. J. Hydrol. 20, 97120.

Lehner, P., 1952. Zur Geologie des Gebietes der Denti della Vecchia, des M. Boglia, des M. Brè, und des M. San Salvatore bei Lugano. Eclogae Geol. Helv. 45, 86-159. Matheron, G., 1963. Principles of geostatistics. Econ. Geol. 58, 1246-1266.

Neuman, S.P., 2005. Trends, prospects and challenges in quantifying flow and transport through fractured rocks. Hydrogeol. J. 13, 124-147.

Nordstrom, D.K., Ball, J.W., Donahoe, R.J., Whittemore, D., 1989. Groundwater chemistry and water-rock interactions at Stripa. Geochim. Cosmochim. Acta 53, 1727-1740.

Pascale, T.F., De Francesco, S., Cuoco, E., Verrengia, G., Santoro, D., Tedesco, D., 2011 Radon hazard in shallow groundwaters II: Dry season fracture drainage and alluvial fan upwelling. Sci. Total Environ. 409, 3352-3363.

Perotti, C.R., 1987. Analisi della fratturazione nella zona di Menaggio (sponda occidentale del Lago di Como). Rend. Soc. Geol. 10, 9-12.

Pozzi, R., 1962. La ricerca geologica delle acque sotterranee. Atti Convegno sul Problema delle acque in Italia, 28-30 ottobre, Milano, pp. 1-17.

Reinhard, M., 1953. Über das Grundgebirge des Sottoceneri im Sud-Tessin. Eclogae Geol. Helv. 46, 214-222.

Renevier, E., 1879. Le gypse des environs de Menaggio (Lac de Come). Bull. Soc. Vaudoise Sci. Nat. 16, 5-10.

Salih, I., Backstrom, M., Karlsson, S., Lund, E., Pettersson, H.B.L., 2004. Impact of fluoride and other aquatic parameters on radon concentration in natural waters. Appl. Radiat. Isotopes 60, 99-104.

Scesi, L., Gattinoni, P., 2007. Roughness control on hydraulic conductivity in fractured rocks. Hydrogeol. J. 15, 201-211.

Schumacher, M.E., Schoenborn, G., Bernoulli, D., Laubscher, H.P., 1996. Rifting and collision in the Southern Alps. In: Pfiffner, O.A. (Ed.), Deep Structure of the Alps. Birkhauser Verlag, Basel, pp. 186-204.

Spalla, M.I., Siletto, G.B., Di Paola, S., Gosso, G., 2000. The role of structural and metamorphic memory in the distinction of tectono-metamorphic units: the basement of the Como lake in the Southern Alps. J. Geodynam. 30, 191-204.

Stetzenbach, K.J., Farnham, I.M., Hodge, V.F., Johannesson, K.H., 1999. Using multivariate statistical analysis of groundwater major cation and trace element concentrations to evaluate groundwater flow in a regional aquifer. Hydrol. Process. 13, 2655-2673.

Terrana, S., Gambillara, R., Scesi, L., Martin, S., Ciceri, E., 2010. Characterization of the Eva Verda basin aquifer (Saint Marcel, Aosta Valley, Italy) through geochemical and geostructural methods and analysis. Hydrogeol. J. 18, 487499.

Vai, G.B., Boriani, A., Rivalenti, G., Sassi, F.P., 1981. Catena Ercinica e Paleozoico nelle Alpi Meridionali. Cento anni di geologia Italiana. Soc. Geol. Ital. 133-154 (Jubilee vol.)

Venzo, S., Maglia, F., 1947. Lembi carboniferi trasgressivi alla "fronte sedimentaria subalpina" del comasco (Acquaseria di Menaggio-Bocchetta di San Bernardo) e del varesotto. Atti Società Italiana Scienze Naturali Museo civico Storia Naturale Milano 6, 33-71.

Wold, S., Esbensen, K., Geladi, P., 1987. Principal component analysis. Chem. Intell. Lab. Syst. 2, 37-52. 